\title{
Dominance of bacterial biomass in the Sargasso Sea and its ecological implications
}

\author{
Jed A. Fuhrman ${ }^{1}$, Thomas D. Sleeter ${ }^{2}$, Craig A. Carlson ${ }^{3}$, Lita M. Proctor ${ }^{4}$ \\ ${ }^{1}$ Department of Biological Sciences, University of Southern California, Los Angeles, California 90089-0371, USA \\ ${ }^{2}$ Bermuda Biological Station for Research, Ferry Reach GE01, Bermuda \\ ${ }^{3}$ Horn Point Environmental Laboratory, University of Maryland, Box 775, Cambridge, Maryland 21613, USA \\ ${ }^{4}$ Marine Sciences Research Center, State University of New York, Stony Brook, New York 11794-5000, USA
}

\begin{abstract}
Despite the recently discovered importance of heterotrophic microorganisms in the structure and function of marine planktonic systems, little is known about the relative significance of these organisms in open-ocean oligotrophic environments. Here we report that depth profiles of planktonic nonphotosynthetic bacteria (BACT), cyanobacteria (CYANO), and both photosynthetic (PNAN) and heterotrophic (HNAN) nanoplankton (i.e. eukaryotes $<20 \mu \mathrm{m}$ diam.) to $2600 \mathrm{~m}$ in the Sargasso Sea in summer and fall (the least productive times of year) indicate that BACT biomass dominates these microorganisms at all depths. From the microscopic counts and our 'best guess' conversion factors, we determined that BACT contain $>70$ and $>80 \%$ of the euphotic zone microbial $\mathrm{C}$ and $N$, respectively, and $>90 \%$ of the biological surface area; CYANO, PNAN, and HNAN biovolume each make up 7 to $17 \%$ of the total. Even calculations based on maximum probable phytoplankton biomass (from chlorophyll) and minimum probable BACT biomass still showed domination by BACT in the euphotic zone. An important practical implication is that conventional measurements of particulate organic $C$ and $N$ collected on glass fiber filters may be missing most of the biomass. Independent bacterial heterotrophic production estimates based on tritiated thymidine incorporation and clearance by nanoplanktonic grazers suggest bacterial division rates of about once per 5 to $15 \mathrm{~d}$. Interpretation of these results suggest that BACT consume significant amounts of $C$ in this system, probably released from phytoplankton directly or via herbivores. These results imply a fundamental difference between oligotrophic and eutrophic waters with respect to biomass distribution and that BACT are major particulate reservoirs of $\mathrm{C}$ and $\mathrm{N}$ in the sea.
\end{abstract}

\section{INTRODUCTION}

Over the past decade the perceived significance of heterotrophic microorganisms in the ocean has increased immensely. We now know that BACT are major components of marine systems, often consuming up to half of the marine primary productivity via dissolved organic matter (DOM) and potentially passing this material to protozoan grazers that also consume small algae (Hagström et al. 1979, Fuhrman \& Azam 1980, 1982, Williams 1981, 1984, Azam et al. 1983, Ducklow 1986, Cho \& Azam 1988). However, most data are from coastal systems and those from the large oligotrophic ocean gyres and deep waters are rare. Knowledge of the processes in these waters is necessary for studying interactions on a global scale as they make up a significant portion of the world ocean.

One of the first steps toward understanding how an ecosystem functions is to know the biomass distribu- tions of the major organisms. Previous work shows that in coastal surface waters, BACT commonly make up 5 to $20 \%$ of the microbial biomass with phytoplankton usually making up most of the rest (Fuhrman et al. 1980, Williams 1981. Holligan et al. 1984), although in summer, when dissolved nutrients are sparse, bacterial biomass sometimes exceeds that of phytoplankton (Boicourt et al. 1987). Recent upward revisions in estimates of biomass per bacterium indicate that many earlier biomass values may be low by about a factor of 2 (see Discussion). Data from oligotrophic ocean sites are rare, but the available measurements suggest a high relative biomass of bacteria (Sieburth \& Davis 1982, Laws et al. 1984), as does a model based on photosynthesis and respiration measurements (Smith et al. 1984). However, these measurements are generally not suitable for quantitative biomass estimates at various depths because they either did not include measurements in comparable units (e.g. C) or only 1 to 2 depths 
were sampled from what are probably heterogeneous depth profiles. Also, biomass estimates based on ATP content do not allow differentiation between different organisms. Two previous reports compared bacterial $C$ to total particulate organic carbon (POC). Maeda et al. (1983) estimated bacterial $C$ in the subtropical Western Pacific from lipopolysaccharide and found it to be several tens of percent of the total POC. A recent report by Cho \& Azam (1988) estimated bacterial $C$ from direct counts and found that bacteria contribute $40 \%$ to POC in the top $100 \mathrm{~m}$ of Central Pacific sites. However, simulaneous measurements of $\mathrm{C}$ or $\mathrm{N}$ biomasses of bacteria, algae, and heterotrophic nanoplankton throughout the upper water column have not previously been reported or discussed.

This study was designed to make such biomass estimates near a well-studied site in the Sargasso Sea (Station S, Menzel \& Ryther 1961). We have also made bacterial growth rate estimates and used the distribution of biomass among different organisms to put reasonable constraints on the flow of matter and energy in the system we examined. We found that bacteria dominated the microbial biomass of this system and also consumed a significant amount of fixed $C_{\text {, prob- }}$ ably mostly released directly from phytoplankton or via herbivores.

\section{MATERIALS AND METHODS}

Water was sampled in Niskin (in 1987) or GO-FLO (in 1988) bottles (both from General Oceanics, Miami, Florida) suspended from a stainless steel hydrowire. Samples were collected at Station $\mathrm{S}\left(32^{\circ} 10^{\prime} \mathrm{N}, 64^{\circ} 30^{\prime} \mathrm{W}\right)$ unless otherwise noted, and all data from a given day were sampled at the same position. Abundance of microorganisms was determined by epifluorescence microscopy of samples filtered onto $25 \mathrm{~mm}$ diam. Nuclepore filters $(0.2 \mu \mathrm{m}$ for prokaryotes, 0.6 or $0.8 \mu \mathrm{m}$ for eukaryotes) and either viewed unstained (CYANO) or stained with acridine orange (BACT, Hobbie et al. 1977) or proflavine (PNAN and HNAN, Haas 1982). Volumes filtered ranged from $5 \mathrm{ml}$ for near-surface BACT counts to $250 \mathrm{ml}$ for CYANO, PNAN, and HNAN from deeper samples. At least 200 bacteria and 100 (near surface) or 50 (deep) CYANO or NAN cells were counted from each slide. BACT sizes were measured for volume estimates from enlarged photographs (Lee \& Fuhrman 1987) and other organisms were sized by ocular micrometer The volume of each cell was calculated from its individual dimensions. Prochlorophytes (Chisholm et al. 1988), which we easily see in oligotrophic samples now that we know what to look for ( $R$. Iturriaga pers. comm.), were probably included in the CYANO counts. Conversion factors for calculation of biomass from biovolume were as follows: BACT were $20 \mathrm{fg} \mathrm{C}$ and $5 \mathrm{fg} \mathrm{N}_{\text {cell }}^{-1}$ (mean conversion $350 \mathrm{fg} \mathrm{C}$ $\mathrm{um}^{-3}$, Lee \& Fuhrman 1987), with the exception of July $1988150 \mathrm{~m}$ samples which had mean bacterial volume $22 \%$ smaller than the smallest studied by Lee \& Fuhrman; these cells were assumed to contain $16 \mathrm{fg} C$ and 4 $\mathrm{fg} \mathrm{N}$ each. CYANO were $250 \mathrm{fg} \mathrm{C}$ and $50 \mathrm{fg} \mathrm{N}_{\text {cell }}{ }^{-1}$ (mean conversion $250 \mathrm{fg} \mathrm{C} \mathrm{m}^{-3}$, Kana \& Glibert 1987),

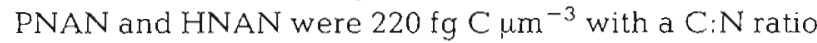
of 7 (Børsheim \& Bratbak 1987). Chl was measured fluorometrically from $>300 \mathrm{ml}$ samples filtered onto $0.45 \mu \mathrm{m}$ Millipore filters and extracted in $90 \%$ acetone (Holm-Hansen et al. 1965). Incorporation of tritiated thymidine into material insoluble in cold trichloroacetic acid was measured according to Fuhrman \& Azam (1982) and the nominal conversion factor to yield production was $4 \times 10^{18} \mathrm{cells} \mathrm{mol}^{-1}$ incorporated (Ducklow \& Hill 1985a).

\section{RESULTS}

Microscopic counts yielded biovolume measurements that consistently showed that BACT dominated the organisms we observed at all depths (Fig. 1, Tables 1 and 2). As BACT had the largest biovolume:biomass conversion factor, the dominance was even more pronounced when results were calculated in terms of $C$ (Fig. 1, Tables 1 and 2). Biomass estimates integrated with depth showed BACT contained $>70 \%$ of the C and $>80 \%$ of the $\mathrm{N}$ from the microorganisms examined in the euphotic zone, and even higher percentages when deeper water is included (Table 2). Data from July 1988 were not integrated with depth because only a few depths were sampled, but at that time the bacterial biomass was particularly high compared to that of other organisms (Table 1) due largely to bacterial abundance 3 to 4 times that of other sampled dates. Calculation of biological surface areas (similar to that done for coastal waters by Williams 1984) from all sample dates showed that, in the euphotic zone, BACT had $>90 \%$. Thus, BACT had by far the greatest potential accessibility to dissolved nutrients or substances, such as radionuclides, that can adsorb to surfaces (Cho $\&$ Azam 1988). Note, when data were integrated to $2600 \mathrm{~m}$, bacteria had $>95 \%$ of the surface area.

We also used chlorophyll (chl) a to independently estimate phytoplankton biomass in the top $150 \mathrm{~m}$. Again conversion to $C$ requires a factor, and we have used 2 approaches. The first is to multiply by a constant C:chl ratio of 50 , and the second assumes the ratio varies with depth such that it is 100 for depths shallower than $50 \mathrm{~m}$ and 40 for depths of $50 \mathrm{~m}$ or more (reasons discussed below). When the constant ratio of 50 is used along with the previous BACT estimates, 
BACT still exceeds the phytoplankton biomass in all but 1 depth from 1 profile, with an average BACT:phytoplankton ratio of 5.2 (Table 3 ). Use of the variable $C$ :chl ratio results in higher phytoplankton $C$ values, and in order to come up with what we believe are minimum likely BACT:phytoplankton ratios we used these in comparison with BACT $C$ estimates reduced by $50 \%$ (i.e. an average of only $10 \mathrm{fg} \mathrm{C}$ cell $^{-1}$ ). Even these estimates, which should exaggerate the relative phytoplankton contribution, show that the bacterial biomass slightly exceeds that of phytoplankton in the samples we examined, with an average biomass ratio of 2.0 for 0 to $150 \mathrm{~m}$ and 1.4 for 0 to $100 \mathrm{~m}$ (Table 3).

Thymidine incorporation was measured from nearsurface samples, and estimates of bacterial secondary production were 4 to $7 \times 10^{7}$ cells $\mathrm{l}^{-1} \mathrm{~d}^{-1}(0.8$ to $1.4 \mu \mathrm{g} \mathrm{C}$ $\mathrm{l}^{-1} \mathrm{~d}^{-1}$ ) in November 1987 , and 13.6 to $31 \times 10^{7}$ cells $\mathrm{l}^{-1} \mathrm{~d}^{-1}$ (or 2.7 to $6.2 \mu \mathrm{C}^{-1} \mathrm{~d}^{-1}$ ) in July 1988 (Table 4).
Estimated bacterial doubling times ranged from 9 to 15 $\mathrm{d}$ in November and 5 to $12 \mathrm{~d}$ in July (Table 4).

\section{DISCUSSION}

\section{How best to measure biomass?}

There are a few possible ways to determine the relative and absolute biomasses of organisms, and each way has its advantages and disadvantages. For our primary method we have chosen to examine the sample by microscopy, estimate the size of each cell, and thus determine the cumulative biovolume of each class of organism. These biovolumes were converted to biomass by conversion factors determined previously for each class of organism. The advantage of this approach is that each organism is categorized and measurements
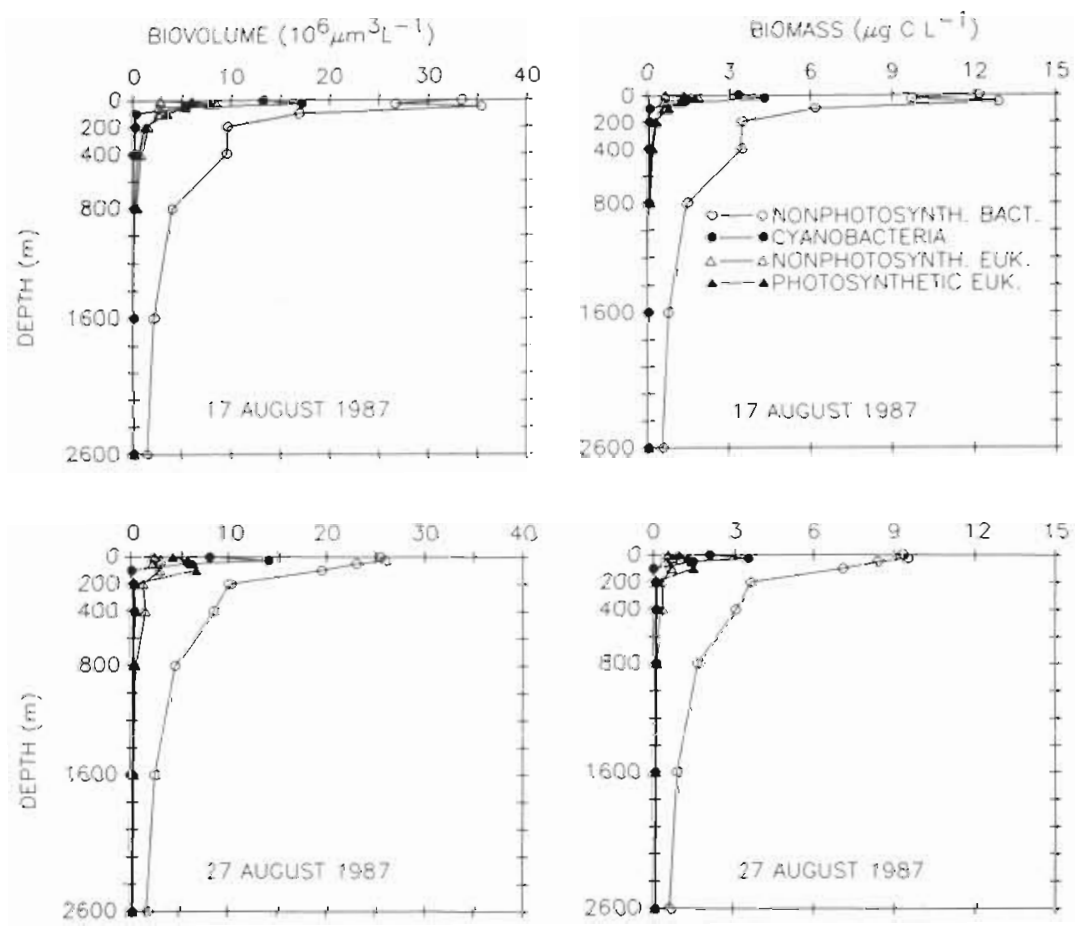

Fig. 1. Depth profiles of biovolumes and calculated $C$ biomasses of organisms from Station S
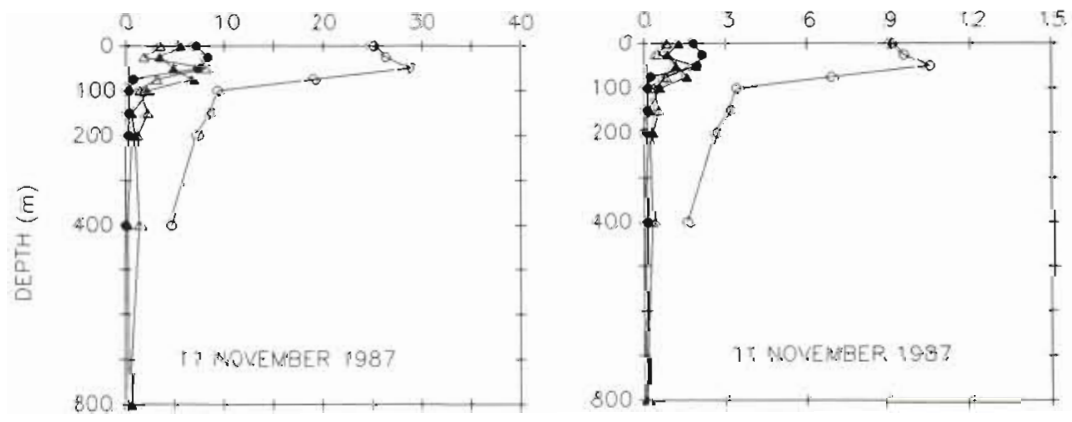
Table 1. Microscopy-based biomass data from stations sampled in July 1988 . Units are: depth in m; no. $1^{-1} \times 10^{8}$ tor $B A C T, \times 10^{6}$ for CYANO, $\times 10^{-5}$ for HNAN and PNAN; biovol. $\times 10^{6} \mu \mathrm{m}^{3}$; cell $\mathrm{C}$ in $\mu g \mathrm{C} \mathrm{L}^{-1}$. BACT: bacteria; HNAN: heterotrophic namoplankton; CYANO: cyanobacteria; PNAN: photosynthetic nanoplankton

\begin{tabular}{|c|c|c|c|c|c|c|c|c|c|c|c|c|}
\hline \multirow[t]{2}{*}{ Depth } & \multicolumn{3}{|c|}{$\mathrm{BACT}$} & \multicolumn{3}{|c|}{ HNAN } & \multicolumn{3}{|c|}{ CYANO } & \multicolumn{3}{|c|}{ PNAN } \\
\hline & No. & Biovol. & Cell C & No. & Biovol. & Cell C & No. & Biovol. & Cell C & No. & Biovol. & Cell C \\
\hline \multicolumn{13}{|c|}{$3 \mathrm{July}$, Station S, $32^{\circ} 10^{\prime} \mathrm{N}, 64^{\circ} 30^{\prime} \mathrm{W}$} \\
\hline 10 & 12.5 & 63.8 & 25 & 4.52 & 4.31 & 0.95 & 24.0 & 10.6 & 2.65 & 10.6 & 17.5 & 3.85 \\
\hline 50 & 15.1 & 89.1 & 30.2 & 5.92 & 6.95 & 1.53 & 21.0 & 5.06 & 1.27 & 1.36 & 3.25 & 0.72 \\
\hline 150 & 7.51 & 21.0 & 12.0 & 2.52 & 2.48 & 0.55 & 2.11 & 0.49 & 0.12 & 3.41 & 5.44 & 1.20 \\
\hline \multicolumn{13}{|c|}{4 July, $32^{\circ} 12^{\prime} \mathrm{N}, 64^{\circ} 35^{\prime} \mathrm{W}$} \\
\hline 10 & 12.1 & 61.7 & 24.2 & 6.09 & 5.79 & 1.27 & 38.5 & 17.2 & 4.27 & 5.41 & 8.92 & 1.97 \\
\hline \multicolumn{13}{|c|}{5 July $^{*}, 32^{\circ} 15^{\prime} \mathrm{N}, 64^{\circ} 36^{\prime} \mathrm{W}$} \\
\hline 10 & 10.9 & 55.6 & 21.8 & 8.89 & 8.46 & 1.86 & 60.6 & 27.1 & 6.77 & 7.76 & 12.8 & 2.82 \\
\hline 50 & 11.5 & 67.8 & 23.0 & 9.28 & 10.9 & 2.4 & 17.3 & 4.12 & 1.03 & 4.32 & 10.3 & 2.27 \\
\hline 150 & 4.4 & 13.3 & 7.0 & 1.51 & 1.5 & 0.33 & 0.35 & 0.08 & 0.02 & 0.37 & 0.59 & 0.13 \\
\hline \multicolumn{13}{|c|}{6 July, $32^{\circ} 10^{\prime} \mathrm{N}, 64^{\circ} 34^{\prime} \mathrm{W}$} \\
\hline 10 & 19.0 & 97.2 & 38.0 & 8.01 & 7.63 & 1.68 & 65.3 & 29.2 & 7.30 & 2.55 & 4.21 & 0.93 \\
\hline 50 & 22.3 & 132 & 44.6 & 7.91 & 9.29 & 2.04 & 35.1 & 8.46 & 2.1 .2 & 4.09 & 9.77 & 2.14 \\
\hline 150 & 3.4 & 9.46 & 5.41 & 331 & 3.26 & 0.72 & 2.01 & 0.47 & 0.12 & 5.25 & 8.37 & 1.84 \\
\hline \multicolumn{13}{|c|}{8 July, $32^{\circ} 19^{\prime} \mathrm{N}, 64^{\circ} 35^{\prime} \mathrm{W}$} \\
\hline 10 & 19.8 & 100 & 39.6 & 7.52 & 7.16 & 1.57 & 66.2 & 29.6 & 7.40 & 5.09 & 8.40 & 1.83 \\
\hline \multicolumn{13}{|c|}{9 July, $32^{\circ} 17^{\prime} \mathrm{N}, 64^{\circ} 33^{\prime} \mathrm{W}$} \\
\hline 10 & 20.6 & 105 & 41.2 & 6.51 & 6.20 & 1.36 & 30.1 & 13.5 & 3.36 & 3.98 & 6.57 & 1.45 \\
\hline \multicolumn{13}{|c|}{$10 \mathrm{July}, 32^{\circ} 17^{\prime} \mathrm{N}, 64^{\circ} 35^{\prime} \mathrm{W}$} \\
\hline 10 & 16.8 & 85.6 & 33.6 & 5.99 & 5.70 & 1.25 & 10.2 & 4.56 & 1.14 & 5.01 & 8.26 & 1.82 \\
\hline
\end{tabular}

Table 2. Depth-integrated microbial data from Station. $S$ in 1987. All values $\mathrm{m}^{-2}$. Same original data as in Fig. 1 Biovol: biovolume $\left(\mathrm{cm}^{3}\right)_{\text {; }} \mathrm{C}$ : carbon $(\mathrm{g})$; $\mathrm{N}$ : nitrogen $(\mathrm{g})$

\begin{tabular}{|c|c|c|c|c|c|c|}
\hline \multirow[t]{2}{*}{ Bacteria } & \multicolumn{3}{|c|}{ Top $150 \mathrm{~m}$} & \multicolumn{3}{|c|}{ Top $2600 \mathrm{~m}$} \\
\hline & Biovol. & C & $N$ & Biovol. & $\mathrm{C}$ & $N$ \\
\hline \multicolumn{7}{|l|}{$17 \mathrm{Aug}$} \\
\hline HNAN & 0.54 & 0.12 & 0.017 & 1.50 & 0.33 & 0.047 \\
\hline PNAN & 0.73 & 0.16 & 0.023 & 1.30 & 0.29 & 0.041 \\
\hline $\mathrm{BACT}$ & 3.70 & 1.34 & 0.335 & 13.0 & 4.76 & 1.189 \\
\hline CYANO & 0.81 & 0.20 & 0.041 & 0.94 & 0.24 & 0.047 \\
\hline \multicolumn{7}{|l|}{27 Aug } \\
\hline HNAN & 0.38 & 0.09 & 0.012 & 1.30 & 0.30 & 0.042 \\
\hline PNAN & 0.91 & 0.20 & 0.029 & 1.10 & 0.24 & 0.034 \\
\hline ВАС Г & 3.30 & 1.20 & 0.300 & 13.0 & 4.82 & 1.204 \\
\hline CYANO & 0.67 & 0.17 & 0.033 & 0.92 & 0.23 & 0.046 \\
\hline 11 Nov & & & & & p 400 & \\
\hline HNAN & 0.46 & 0.10 & 0.015 & 0.77 & 0.17 & 0.016 \\
\hline PNAN & 0.53 & 0.12 & 0.017 & 0.64 & 0.14 & 0.016 \\
\hline $\mathrm{BACT}$ & 2.70 & 0.99 & 0.248 & 4.27 & 1.55 & 0.270 \\
\hline CYANO & 0.49 & 0.12 & 0.024 & 0.49 & 0.12 & 0.024 \\
\hline
\end{tabular}

are straightforward. This method yields a direct measurement of biovolumes, which are themselves useful as biomass indicators. Also, the cell count and size data are necessary for examining the effects of size-selective grazing and determining the impact of different types of organisms on marine optical properties. The disadvantages include (1) conversion to $\mathrm{C}$ or $\mathrm{N}$ requires a factor that is not constant and tends to decrease with increasing size (Strathmann 1967); (2) some cells may be missed because they may become unrecognizable 
Table 3. Comparison of bacterial biomass and chlorophyll-based phytoplankton biomass estimates. Depth (m); chl a ( $\mu \mathrm{g} \mathrm{l}^{-1}$ ); BACT $\left(u g \mathrm{Cl}^{-1}\right)$; PHYT1 $=$ chl a $\times 50 ;$ LOWBACT $=$ BACT/2; PHYT2 $=$ chl a $\times 100$ if depth $<50 \mathrm{~m}$ or $\times 40$ if depth $\geq 50 \mathrm{~m}$

\begin{tabular}{|c|c|c|c|c|c|}
\hline Date & Depth & Chl a & $\mathrm{BACT}$ & BACT/PHYT1 & LOWBACT/PHYT2 \\
\hline 17 Aug 1987 & $\begin{array}{r}1 \\
25 \\
50 \\
100\end{array}$ & $\begin{array}{l}0.057 \\
0.071 \\
0.075 \\
0.070\end{array}$ & $\begin{array}{r}12.2 \\
9.7 \\
12.9 \\
6.4\end{array}$ & $\begin{array}{l}4.3 \\
2.7 \\
3.4 \\
1.8\end{array}$ & $\begin{array}{l}1.07 \\
0.68 \\
2.15 \\
1.10\end{array}$ \\
\hline 27 Aug 1987 & $\begin{array}{r}1 \\
25\end{array}$ & $\begin{array}{l}0.037 \\
0.05\end{array}$ & $\begin{array}{l}9.3 \\
9.4\end{array}$ & $\begin{array}{l}5.0 \\
3.8\end{array}$ & $\begin{array}{l}1.25 \\
0.94\end{array}$ \\
\hline 11 Nov 1987 & $\begin{array}{r}1 \\
25 \\
50 \\
75 \\
100 \\
150\end{array}$ & $\begin{array}{l}0.05 \\
0.08 \\
0.20 \\
0.25 \\
0.04 \\
0.01\end{array}$ & $\begin{array}{r}9.0 \\
9.6 \\
10.4 \\
6.9 \\
3.4 \\
3.1\end{array}$ & $\begin{array}{l}3.6 \\
2.4 \\
1.0 \\
0.6 \\
1.7 \\
6.2\end{array}$ & $\begin{array}{l}0.90 \\
0.60 \\
0.65 \\
0.35 \\
1.06 \\
3.89\end{array}$ \\
\hline 3 Jul 1988 & 10 & 0.05 & 33.8 & 13.5 & 3.38 \\
\hline 4 Jul 1988 & 10 & 0.094 & 24.2 & 5.2 & 1.29 \\
\hline 5 Jul 1988 & $\begin{array}{r}10 \\
50 \\
150\end{array}$ & $\begin{array}{l}0.105 \\
0.140 \\
0.009\end{array}$ & $\begin{array}{r}24.6 \\
25.1 \\
7.0\end{array}$ & $\begin{array}{r}4.7 \\
3.6 \\
15.6\end{array}$ & $\begin{array}{l}1.17 \\
2.27 \\
9.75\end{array}$ \\
\hline $9 \mathrm{Jul} 1988$ & 10 & 0.059 & 41.2 & 14.0 & 3.49 \\
\hline
\end{tabular}

Table 4. Estimates of bacterial production rates from thymidine incorporation. Samples are from $20 \mathrm{~m}$ depth in $\mathrm{Nov}^{\prime}\left(32^{\circ} 18^{\prime} \mathrm{N}, 64^{\circ} 33^{\prime}\right.$ W) and $10 \mathrm{~m}$ in Jul (locations as in Table 1). TdR inc.: measurements are from triplicate samples and duplicate blanks; mean coefficient of variation of triplicates was $10.2 \%$, Doublingtime assumes $4 \times 10^{18}$ cells produced mol ${ }^{-1}$ thymidine incorporated, see text for discussion of alternate possible factors

\begin{tabular}{|c|c|c|c|c|}
\hline Date & $\begin{array}{c}\text { TdR inc. } \\
\left(10^{-11} \mathrm{~mol} \mathrm{l}^{-1} \mathrm{~d}^{-1}\right)\end{array}$ & $\begin{array}{c}\text { Growth } \\
\left(10^{7} \text { cells } ~^{-1} d^{1}\right)\end{array}$ & $\begin{array}{l}\text { Production } \\
\left.\text { ( } \text { ( g C } ~^{-1} d^{1}\right)\end{array}$ & $\begin{array}{l}\text { Doubling time } \\
\text { (d) }\end{array}$ \\
\hline 3 Nov 1987 & 0.99 & 3.94 & 0.79 & 15.2 \\
\hline 4 Nov 1987 & 1.64 & 6.56 & 1.31 & 9.5 \\
\hline 6 Nov 1987 & 1.74 & 6.96 & 1.39 & 8.6 \\
\hline 4 Jul 1988 & 6.07 & 24.3 & 4.85 & 5.0 \\
\hline 5 Jul 1988 & 5.82 & 23.3 & 4.65 & 4.7 \\
\hline 6 Jul 1988 & 7.75 & 31.0 & 6.19 & 6.1 \\
\hline 9 Jul 1988 & 7.18 & 28.7 & 5.74 & 7.2 \\
\hline 10 Jul 1988 & 3.40 & 13.6 & 2.72 & 12.4 \\
\hline
\end{tabular}

during preparation for microscopy; and (3) rare large cells may contribute much biomass but be missed because they are not in the small volume actually examined.

Choosing the best conversion factors is problematic, particularly for bacteria. Until a few years ago, it was generally assumed that values determined for cultured bacteria, such as Escherichia coli, could simply be applied to marine bacteria. However, several investigators in recent years have measured the bacterial conversion factor by numerous approaches, and these have generally found much higher values, (i.e. 2 to 5 times), of $C$ per unit biovolume than were previously used (Bratbak 1985, Bjørnsen 1986, Lee \& Fuhrman 1987). We suggest that the most appropriate conversion factor is the 1 generated by methods that closely follow those used for natural samples; in this way errors or artifacts can cancel out and are least likely to affect the final result. Therefore we have chosen to use the factor from Lee \& Fuhrman (1987) which is derived from measurements of $\mathrm{POC}$ and $\mathrm{N}$ in combination with cell size measurements made by the exact same procedure as we used in this study. Bacterial sizing criteria were calibrated with fluorescent latex beads. The bacteria in Lee and Fuhrman's study were natural marine bacteria inoculated into and grown in particle-free seawater (thus eliminating detritus), and the size range of these bacteria in 'seawater cultures' bracketed those of the bacteria we found in the Sargasso Sea (except for the 5 July $1988150 \mathrm{~m}$ sample, for which we adjusted the 
calculations). Note also that this conversion factor is very close to that of Bjørnsen (1986), determined by a different method.

In our attempt to determine the minimum likely ratio of bacterial:phytoplankton biomass, we deliberately made a low estimate of bacterial biomass by using $10 \mathrm{fg}$

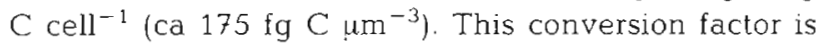
lower than those of all the reports cited above.

Regarding the conversion factors for other organisms, we have used values we believe are most appropriate. For cyanobacteria, there are few studies that report $\mathrm{C}$ and $\mathrm{N}$ for marine Synechococcus, and we have chosen a recent one that has the necessary data (Kana \& Glibert 1987). That factor fits in with the general curve of higher cell $\mathrm{C}$ and $\mathrm{N}$ content per unit volume with decreasing cell size. This is also the case for our conversions for PNAN and HNAN. We cite a recent study that performs cell size measurements similar to ours with organisms of similar sizes (Børsheim \& Bratbak 1987). We also note that this is the same conversion factor that is obtained from the oft-cited biovolume: biomass regression of Strathmann (1967) for cells of 3 to 4 um diam., which is the average nanoplankton cell size in our euphotic zone samples.

We tried to gauge the potential significance of disadvantages (2) and (3) by independently estimating biomass of phytoplankton from measurements of chl a. This avoids loss of delicate or rare cells because the chi is extracted from several hundred milliliter volumes on filters that do not allow chl-containing particles to pass, so both delicate and rare cells are included in the measurement. However, interpreting chl measurements in terms of biomass has its own disadvantages. For example, the measurement of chl a by the standard fluorometric method may be high if there is significant chl $b$ present. While this was not previously considered important in seawater, the recent discovery of abundant marine prochlorophytes (Chisholm et al. 1988) may change matters. This interference can be eliminated by chromatographic methods, but was not done so in this study. A more well-established problem is that the conversion from $\mathrm{chl}$ to $\mathrm{C}$ requires a factor that is not constant and varies between species and with growth conditions, particularly nutrient and light levels (see Banse 1.977).

We chose to use 2 different methods to calculate $C$ biomass from chl measurements. It was our intent to be reasonably close yet to avoid underestimates by tending to the high side. Our reason for this is to see if our observation of bacterial dominance is robust to overestimated phytoplankton biomass and underestimated bacterial biomass; if we exaggerate the phytoplankton biomass estimate yet we still find a high BACT:phytoplankton ratio, this would more convincingly demonstrate the high relative bacterial biomass in the waters we examined. The first method is to apply a constant ratio of 50 . This is considerably higher than the value of 30 proposed for field samples by Strickland (1960). It is also slightly higher than the ratio of 46 found by Laws et al. (1987) for oligotrophic Pacific waters. It should be pointed out that pure cultures often show ratios of 15 to 20 (Welschmeyer \& Lorenzen 1984, Geider et al. 1986), particularly at low light levels, such as those in deeper waters. We have tried to take into account the effects of light adaptation (Beardall \& Morris 1976) by our second method which used a ratio of 40 for deep waters and 100 for shallow. Because most of the chl was deep, and the true ratio for these organisms can be as low as 15 to 20 , we believe that this approach should provide particularly generous calculations of phytoplankton biomass. The results indicated that even with these high phytoplankton and low bacterial biomass estimates, the bacterial biomass still dominates.

An alternative way to determine if we missed significant phytoplankton biomass is to calculate $\mathrm{C}$ : chl ratios from our data directly. Such a ratio would be unreasonably low if we missed much phytoplankton. Our own estimates of these ratios, where $\mathrm{C}$ is the sum of CYANO and PNAN, are $81.4 \pm 8.7$ (mean $\pm \mathrm{SE}$ ) for $<50 \mathrm{~m}$ and $17.0 \pm 4.1$ for 50 to $100 \mathrm{~m}$ (for samples whose chl data are shown in Table 3 ). These compare favorably with ratios from the literature as discussed above, and further indicate that our phytoplankton biomass estimates are in the reasonable range.

The idea that we may be missing large rare algae becomes important to our conclusions only if such cells represent a significant portion of the biomass. Previous studies show that the vast majority of oligotrophic ocean algae are only a few microns or less in diameter (Li et al. 1983, Takahashi \& Hori 1984, Glover et al. 1986, Stockner \& Antia 1986). Our own size fractionation showed $34 \pm 4.4 \%$ (in November 1987) and $50 \pm$ $2.7 \%$ (in July 1988) of the total near-surface chl a was collectable on $1.0 \mu \mathrm{m}$ Nuclepore filters, and on the 1 instance tested (25 August 1987), only $6 \%$ of chl at $10 \mathrm{~m}$ was caught on $10 \mu \mathrm{m}$ Nitex mesh. Such size data are consistent with our own observed distribution of CYANO and PNAN, and inconsistent with significant biomass in large rare cells. These data plus those from the literature cited above support the notion that the small common forms represented most of the phytoplankton biomass, so underestimates due to missing large rare forms would be minor Also note that the possibility that major algal layers occurred between our sampling depths was checked (in August) by examining more finely-spaced (every $10 \mathrm{~m}$ ) chl measurements, and these showed no such peaks.

Although we did not measure POC in this study, we can compare our results to data from the literature. Gordon (1977) reported an average of $14.4 \mathrm{ugC}^{-1}$ from 
0 to $100 \mathrm{~m}$ depths over 25 measurements $(8$ cruises, 2 yr) at a sampling location near Bermuda $(158 \mathrm{~km}$ northnortheast of Station S). Our own average cumulative biomass estimates (all microorganisms combined), averaged over the top $150 \mathrm{~m}$ were 8.9 to $12.1 \mathrm{\mu g} \mathrm{Cl}^{-1}$ for 1987 (depth-integrated data from Table 2). In July 1988, the biomass was much higher, averaging $31.2 \mu \mathrm{g}$ $\mathrm{C}^{-1}$ (summed data from Table 1). Thus our biomass estimates averaged 62 to $217 \%$ of the mean POC value from the literature. However, these POC measurements were made with silver filters with a rated pore size of $0.8 \mu \mathrm{m}$. Such filters probably allow significant bacterial biomass (typical diam. $0.5 \mu \mathrm{m}$ ) to pass, but we do not know how much, especially because precombustion may have affected the pore size. We know of no POC measurements that were made from filters that quantitatively collect bacteria. Because bacteria made up $>70 \%$ of our total biomass estimates and were represented by an unknown amount in the POC measurements, it is difficult to make meaningful comparisons.

\section{Practical implications}

The first practical implication of these results is that measurements of parameters such as biomass or POC and $\mathrm{N}$ must be done in such a way as to avoid missing bacteria, many of which are $<0.5 \mu \mathrm{m}$ in diam. This represents a challenge as most conventional measurements use glass fiber filters (e.g. Whatman GF/F) that can pass typically half or more of the bacteria (Lee \& Fuhrman 1987). It may be necessary to use $0.2 \mu \mathrm{m}$ pore size filters made from aluminum oxide or silver despite their slow filtration rates. Secondly, the measurements should reflect a system dominated by bacteria, which are rich in $\mathrm{N}$ and $\mathrm{P}$ (largely due to a high nucleic acid content), and have very large surface:volume ratios. Third, the bacteria may be the major factor influencing light scattering, absorption, and certain other optical phenomena in the open ocean currently ascribed mainly to algae. This latter point is relevant for interpretation of satellite imagery, as in open ocean environments the bacteria can contribute significantly to the optical properties observed by satellites (Chamberlain 1988).

\section{Bacterial growth rates}

Interpretation of our depth-integrated biomass data (Table 2) suggests that BACT are probably growing much more slowly in oligotrophic areas than in eutrophic coastal areas, based on considerations of both $\mathrm{C}$ supply rate and clearance by grazers. For the oligo- trophic bacteria to divide once $d^{-1}$, as may occur in warm coastal areas (Hagström et al. 1979, Fuhrman \& Azam 1980, 1982, Williams 1981), at 50\% gross growth efficiency they must consume $C$ equivalent to 7 phytoplankton biomasses $\mathrm{d}^{-1}$ (all as DOM), as determined from the depth-integrated biomass ratios between these groups (Table 2; calculated from the equation: Consumption $=$ biomass $\times$ turnover rate $/$ gross growth efficiency). There is no evidence that phytoplankton or other organisms can generate sufficient organic $C$ to support this even if recycling of DOM within the food web is included; phytoplankton population turnover rates are believed to be 0.5 to $2 \mathrm{~d}^{-1}$ in oligotrophic waters (Laws et al. 1987 and references therein). The higher ratio of bacterial to phytoplankton biomass in many of the samples from July (Table 1) suggests that the problem of $\mathrm{C}$ supply to bacteria may have been even more acute then. Also, to maintain a steady state at 1 bacterial doubling $\mathrm{d}^{-1}$, grazing by HNAN (currently thought to be the major bacterivores; Azam et al. 1983) would require specific clearance rates of $>10^{7}$ body volumes $h^{-1}$, and this is 1 to 2 orders of magnitude faster than previously reported clearance rates by such grazers (Fenchel 1986, Sherr \& Sherr 1987). The latter problem might be lessened if bacteria were aggregated or if there were additional grazers or loss mechanisms, but the phytoplankton production problem would still occur. However, if bacterial populations were turning over every 5 to $15 \mathrm{~d}$, there is no problem reconciling the results. It should be added that if we use bacterial gross growth efficiencies as high as $75 \%$, it is still difficult to reconcile turnover times much less than $5 \mathrm{~d}$. It must be emphasized that these are population averages, and that subpopulations can grow much faster or slower. Also, it must be kept in mind that phytoplankton must also ultimately feed significant populations of macrozooplankton, whose biomass may be similar to that of phytoplankton (Deevey 1971); however, these organisms generally turn over much more slowly than do bacteria, and food web cycling permits zoolankton production to be fueled by primary production both before and after the primary production has passed through the bacteria.

Our direct field estimates of bacterial production and population turnover suggest bacterial turnover times of about $10 \mathrm{~d}$ in near-surface samples (Table 4), although we acknowledge that there is still much uncertainty in such estimates. This thymidine-based estimate is likely to be within a factor of 2, as determined empirically with offshore samples from the oligotrophic North Atlantic (Ducklow \& Hill 1985a). Use of a lower factor, such as the $2.0 \times 10^{18}$ determined for samples from the Pacific by Fuhrman \& Azam (1982), would yield proportionally slower growth rate estimates, and higher factors would of course yield faster estimates (but see 
limitations above). Because there are few tests of conversion factors from oligotrophic environments, the value from Ducklow \& Hill represents our 'best guess'. We have also made an independent estimate of bacterial population turnover by assuming a specific clearance rate, i.e., body volumes cleared $\mathrm{h}^{-1}$ for the HNAN and also for HNAN + PNAN. With an estimated clearance rate of $5 \times 10^{5}$ body volumes cleared $\mathrm{h}^{-1}$, and based upon the depth-integrated biomasses shown in Table 2, HNAN alone would turn over the bacterial biomass every 23 to $32 \mathrm{~d}$, and HNAN + PNAN would do so every 10 to $13 \mathrm{~d}$. For the data from July 1988 (Table 1, excluding $150 \mathrm{~m}$ data), HNAN alone would turn over the bacterial biomass every $16 \pm 3.3 \mathrm{~d}$ (mean \pm SE) and HNAN + PNAN every $6.1 \pm 0.9 \mathrm{~d}$. These grazing-based estimates assume a specific clearance rate that is at the high end of the range reported for all bacterivores (Fenchel 1986, Sherr \& Sherr 1987), so it is a maximum value suitable for setting limits; more conservative rates are about $1 / 5$ as fast so would yield a 5 fold longer turnover time. We made 2 different grazingbased estimates because we are uncertain if the pigmented nanoplankton graze bacteria. There are few data available on this question from field samples (Estep et al. 1986), although it should be realized that some of the forms identified by single cell fluorescence as containing chl may actually be heterotrophs that recently ingested an algal cell (although often the cell morphology seems to exclude this possibility). The grazing-based turnover time estimates will be too long if there is significant bacterial aggregation ('tracked' by the grazers) or there are other grazers, such as larger protozoa, or other currently ill-defined but potentiallysignificant loss mechanisms, such as viruses.

It is somewhat encouraging that the thymidine and grazing based estimates are in the same general range. Also we find it interesting that even with a maximal estimate from these high specific clearance rates, it takes both HNAN and PNAN to turn over the bacterial biomass at rates comparable to the thymidine-based rates. If the thymidine estimate is reasonable, this suggests that either PNAN are important grazers or that there are other major bacterial loss mechanisms besides HNAN grazing. Preliminary experiments indicate that viral infection may be an important source of mortality (Proctor et al, 1988, unpubl.), and there may be important larger grazers such as ciliates, so PNAN grazing of bacteria need not be invoked.

\section{Ecological implications of biomass distributions}

How can a system maintain itself with heterotrophic biomass exceeding that of autotrophs? It seems that the phytoplankton organic C must maintain a faster turn- over than bacterial $C$ in order for algae to supply $C$ to bacteria, as discussed above. The 2 elements of turnover are production and loss rates, which are balanced (equal) at steady state. To simplify discussion, we will assume the system usually approaches steady state; this assumption is consistent with our observations, though we realize that perturbations are probably common. Loss from phytoplankton can be through processes such as grazing or through leakage of DOM. Of the 2 , direct leakage is more efficient at providing bacteria with $C$ because, from grazing, the DOC usable by bacteria must come via indirect routes such as 'sloppy feeding' excretion, and egestion (Eppley et al. 1981), and much of what is assimilated by grazers is respired.

Furthermore there is the question of how quasisteady state is maintained when heterotrophs and autotrophs are presumably turning over at different rates yet are similar in size (HNAN vs PNAN, and CYANO vs BACT) and thus presumably available for grazing by the same organisms. Put another way, how do 2 groups of similar-sized organisms (CYANO and BACT) coexist near steady state when 1 of them is turning over roughly 7 times faster than the other (determined from relative biomasses and assuming $50 \%$ bacterial gross growth efficiency)? One possibility is discrimination against heterotrophs by grazers. Some discrimination may be due to size. Fenchel (1986) has calculated that for a swimming chrysomonad the clearance rate is proportional to the square of the radius of the prey. Our measurements of BACT and CYANO suggest that CYANO have roughly twice the average diameter of BACT (1.0 vs $0.5 \mu \mathrm{m})$, so size discrimination may account for a factor of 4 difference in clearance rate. However with grazing as the sole phytoplankton loss mechanism, there is still the need to explain how sufficient organic $\mathrm{C}$ reaches bacteria. The greater the proportion of grazing vs leakage, the more DOM grazers must release to feed bacteria (i.e. if release is less, then BACT turnover becomes even slower and more discrimination is required to maintain steady state). Unless there is extreme discrimination against bacteria, which seems unlikely given that they are the major biomass present (i.e. biggest potential food source), 1 obvious way to balance the system is to invoke a large release of DOM directly from phytoplankton.

A large direct release of DOM from phytoplankton has been demonstrated in some studies (Ignatiades \& Fogg 1973, Lancelot 1979), and there are also reports of diel changes in dissolved 'carbohydrates' (Johnson et al. 1981). However, most reports suggest direct release is small (see Jumars et al. 1989). Note that incubation experiments may fail to detect such release if the material is quickly taken up by bacteria and respired, or, if the incubation conditions somehow inhibit release. It is important to ask why phytoplankton might 
release large amounts of DOM. It is possible that they have no choice (Bjornsen 1988) or perhaps they are 'farming' the bacteria for production of vitamins or other necessary substances (Haines \& Guillard 1974); perhaps some leakage is due to viral infection of the phytoplankton. However, the arguments above do not require most DOM to be released directly from phytoplankton, they only suggest it is the simplest pathway. Release as a result of grazing processes ('sloppy feeding', egestion, excretion) may be equally or more important (Eppley et al. 1981, Jumars et al. 1989), yet as discussed above, grazing as the major agent of CYANO turnover implies that grazers are highly selective against $\mathrm{BACT}$. An interesting alternative to phytoplankton as a source of DOM is solar-induced photochemical production of labile low molecular weight organic compounds (e.g. aldehydes, keto-acids) from high molecular weight refractory DOM (Mopper et al. 1987). This potential source of $C$ represents an import to the oligotrophic system, as refractory DOC is generally very old and could have been generated in distant locations. Preliminary calculations (K. Mopper pers. comm.) suggest that this potential $\mathrm{C}$ source is probably less significant than phytoplankton production when integrated over the euphotic zone (i.e. $<1 \mu \mathrm{g} \mathrm{Cl}^{-1} \mathrm{~d}^{-1}$ ), but more work must be done. Another exogenous source of DOM is rainwater, which can also contain readily-utilizable compounds (Mopper \& Zika 1987).

It will be important to learn if bacteria are limited by energy (i.e. organic $C$ ) or other nutrients such as $N$. This question is highly relevant to understanding oligotrophic marine productivity when bacterial biomass exceeds that of phytoplankton as we have measured. In a system where $N$ is probably the limiting nutrient (Ryther \& Dunstan 1971), bacterial sequestration of $\mathrm{N}$ must have major ecological consequences. Because bacteria have such a large biomass and surface area, they could easily outcompete the phytoplankton for $N$ (Fuhrman et al. 1988), and in the process would regulate the major $\mathrm{C}$ supply for the system (unless photochemical DOM production is very significant). They may also be the major particulate reservoirs of available limiting nutrients in the system, so their turnover may partly control the availability of dissolved nutrients. Because oligotrophic systems are characterized by very slow replenishment of nutrients through vertical mixing and diffusion, it is likely that the bacterial sequestration of nutrients in such a system is a consequence of the fact that bacteria sink very slowly compared to larger plankton and detritus; the more rapidly-sinking particles cannot maintain significant steady state concentrations in the euphotic zone. Note also that those algae that can consume bacteria may tap into this large nutrient supply directly.
We are not certain how universal our results are to the open ocean in general or even to our study area in other seasons. An exception to our observed pattern from the Sargasso Sea is that phytoplankton apparently dominate warm core Gulf Stream rings, and bacteria apparently grow faster there (Ducklow \& Hill 1985b, Ducklow 1986), but this seems to be due to phytoplankton growth stimulated by ring-related physical processes. Phytoplankton dominance and more rapid bacterial growth probably also occur during algal blooms in the spring or following intermittent mixing or upwelling events. However, bacterial and algal biomass data similar to ours have been found at various sites and times in the Pacific by Cho \& Azam (unpubl.), and bacterial abundance and chlorophyll measurements very similar to ours have been found in the Western tropical Pacific by Maeda et al. (1983). These results suggest we are describing a general phenomenon for much of the sea and that interactions among autotrophic and heterotrophic microorganisms are among the most important factors controlling the productivity of the open ocean.

Acknowledgements. We thank A. Chan and Dr C. Suttle for assistance with measurements, Dr T. Jickells for fine-scale chlorophyll data, and Dr H. Ducklow and Dr M. Clarholm for reviewing earlier versions of the manuscript. This work was supported by NSF grants OCE-8410074, OCE-8711132, OCE8716903, and a Riker Fellowship at Bermuda Biological Station.

\section{LITERATURE CITED}

Azam, F., Fenchel, T., Field, J. G., Meyer-Reil, L. A., Thingstad, F. (1983). The ecological role of water-column microbes in the sea. Mar. Ecol. Prog. Ser. 10: 257-263

Banse, K. (1977). Determining the carbon-to-chlorophyll ratio of natural phytoplankton. Mar. Biol. 41: 199-212

Beardall, J., Morris, I. (1976). The concept of light intensity adaptation in marine phytoplankton: some experiments with Phaeodactylum tricornutum. Mar. Biol 37: 377-388

Bjornsen, P. K. (1986). Automatic determination of bacterioplankton biomass by image analysis. Appl. envirl Microbiol. 51: 1199-1204

Bjørnsen, P. K. (1988). Phytoplankton exudation of organic matter: Why do healthy cells do it? Limnol. Oceanogr. 33: 151-154

Boicourt, W. C., Chao, S. Y., Ducklow, H. W., Glibert, P. M. Malone, T. C., Roman, M. R., Sanford, L. P., Fuhrman, J. A., Garside, C., Garvine, R. W (1987). Physics and microbial ecology of a buoyant estuarine plume on the continental shelf. EOS Trans. Am. geophys. Un. 68: 666-668

Borsheim, K. Y., Bratbak, G. (1987). Cell volume to cell carbon conversion factors for a bacteriovorous Monas species enriched from seawater. Mar. Ecol. Prog. Ser. 36: 171-175

Bratbak, G. (1985). Bacterial biovolume and biomass estimation. Appl. envirl Microbiol. 49: 1488-1493

Chamberlain, W. S. (1988). Light absorption, natural fluorescence and photosynthesis in the open ocean. Ph. D. Dissertation. Univ. Southern California, Los Angeles 
Chisholm, S. W., Olson, R. J., Zettler, E. R., Goericke, R., Waterbury, J. B., Welschmeyer, N. A. (1.988). A novel freeliving prochlorophyte abundant in the oceanic euphotic zone. Nature Lond. 334: 340-343

Cho, B. C., Azam, F. (1988). Major role of bacteria in biogeochemical fluxes in the ocean's interior. Nature, Lond. 332: 441-443

Deevey, G. B. (1971). The annual cycle in quantity and composition of the zooplankton of the Sargasso Sea off Bermuda. I. The upper $500 \mathrm{~m}$. Limnol. Oceanogr. 16: 219-240

Ducklow, H. W. (1983). The production and fate of bacteria in the oceans. BioSci. 33: 494--501

Ducklow, H. W. (1986). Bacterial biomass in warm-core Gulf Stream ring 82-B: mesoscale distributions, temporal changes and production. Deep Sea Res. 33: 1789-1812

Ducklow, H. W., Hill, S. M. (1985a). Tritiated thymidine incorporation and the growth of heterotrophic bacteria in warm core rings. Limnol. Oceanogr. 30: 260-272

Ducklow, H. W., Hill. S. M. (1985b). The growth of heterotrophic bacteria in the surface waters of warm core rings. Limnol. Oceanogr. 30: 239-259

Eppley, R. W., Horrigan, S. G., Fuhrman, J. A., Brooks, E. R. Price, C. C., Sellner, K. (1981). Origins of dissolved organic matter in Southern California coastal waters: experiments on the role of zooplankton. Mar. Ecol. Prog. Ser. 6: 149-159

Estep, K. W., Davis, P. G., Keller, M. D., Sieburth, J. M. (1986). How important are oceanic algal nanoflagellates in bacterivory? Limnol. Oceanogr. 31: 646-649

Fenchel, T. (1986). Protozoan filter feeding. Prog. Protistol. 1. $65-114$

Fuhrman, J. A., Ammerman, J. W., Azam, F. (1980). Bacterioplankton in the coastal euphotic zone: distribution, activity, and possible relationships with phytoplankton. Mar. Biol. 60: 201-207

Fuhrman, J. A., Azam, F. (1980). Bacterioplankton secondary production estimates for coastal waters of British Columbia, Antarctica, and Southern California. Appl. envir. Microbiol. 39: 1085-1095

Fuhrman, J. A., Azam, F. (1982). Thymidine incorporation as a measure of heterotrophic bacterioplankton production in marine surface waters: evaluation and field results. Mar Biol. 66: 109-120

Fuhrman, J. A., Horrigan, S. G., Capone, D. G. (1988). Use of ${ }^{13} \mathrm{~N}$ as tracer for bacterial and algal uptake of ammonium from seewater. Mar. Ecol. Prog. Ser. 45: 271-278

Geider, R. J., Platt, T., Raven, J. A. (1986). Size dependence of growth and photosynthesis in diatoms: a synthesis. Mar Ecol. Prog. Ser. 30: 93-104

Glover, H. E., Campbell, L., Prézelin, B. B. (1986). Contribution of Synechococcus spp. to size-fractionated primary productivity in three water masses in the Northwest Atlantic Ocean. Mar. Biol. 91: 193-203

Gordon, D. C. (1977). Variability of particulate organic carbon and nitrogen along the Halifax-Bermuda section. Deep Sea Res. 24: 257-270

Haas, L. W. (1982). Improved epifluorescence microscopy for observing planktonic micro-organisms. Annls Inst. oceanogr., Paris $58(5) \cdot 261-266$

Hagström, A., Larsson, U., Horstedt, P., Normark, S. (1979). Frequency of dividing cells, a new approach to the determination of bacterial growth rates in aquatic environments. Appl. envir. Microbiol. 37. 805-812

Haines, K. C. Guillard, R. R. L. (1974). Growth of vitamin B12requiring marine diatoms in mixed laboratory cultures with vitamin B12-producing marine bacteria. J. Phycol. 10: $245-252$

Hobbie, J. E., Daley, R. J., Jasper, S. (1977). Use of Nuclepore filters for counting bacteria by fluorescence microscopy. Appl. envir. Microbiol. 33: 1225-1228

Holligan, P. M., Harris, R. P., Newell, R. C., Harbour, D. S., Head, R. N., Linley, E. A. S., Lucas, M. I., Tranter, P. R. G., Weekly, C. M. (1984). Vertical distribution and partitioning of organic carbon in mixed, frontal and stratified waters of the English Channel. Mar. Ecol. Prog. Ser 14: $111-127$

Holm-Hansen, O., Lorenzen, C. J., Holmes, R. W., Strickland, J. D. H. (1965). Fluorometric determination of chlorophyll. J. Cons. perm. int. Explor. Mer. 30: 3-15

Ignatiades, L., Fogg, G. E. (1973). Studies on the factors affecting the release of organic matter by Skeletonema costatum (Greville) Cleve in culture. J. mar, biol. Ass. U.K. 53: $937-956$

Johnson, K. M., Burney, C. M., Sieburth, J. McN. (1981). Enigmatic marine ecosystem metabolism measured by direct diel SIGMA $\mathrm{CO}_{2}$ and $\mathrm{O}_{2}$ flux in conjunction with DOC release and uptake. Mar. Biol. 65: 49-60

Jumars, P. A., Penry, D. L., Baross, J. A., Perry, M. J., Frost, B. W. (1989). Closing the microbial loop: dissolved carbon pathway to heterotrophic bacteria from incomplete ingestion, digestion, and absorption in animals. Deep Sea Res. 36: $483-495$

Kana, T., Glibert, P. M. (1987). Effect of irradiances up to 2000 $\mu \mathrm{Em}^{-2} \mathrm{~s}^{-1}$ on marine Synechococcus WH 7803-I. Growth, pigmentation, and cell composition. Deep Sea Res. 34: $479-516$

Lancelot, C. (1979). Gross excretion rates of natural marine phytoplankton and heterotrophic uptake of excreted products in the southern North Sea, as determined by shortterm kinetics. Mar. Ecol. Prog. Ser. 1. 179-186

Laws, E. A., DiTullio, G. R., Redalje, D. G. (1987). High phytoplankton growth and production rates in the North Pacific subtropical gyre. Limnol. Oceanogr. 32: 905-918

Laws, E. A., Redalje, D. G., Haas, L. W., Bienfang, P. K., Eppley, R. W., Harrison, W G., Karl, D. M., Marra, J. (1984). High pyhtoplankton growth and production rates in oligotrophic Hawaiian coastal waters. Limnol. Oceanogr. 29: 1161-1169

Lee, S., Fuhrman, J. A. (1987). Relationships between biovolume and biomass of naturally derived marine bacterioplankton. Appl. envir Microbiol. 53: 1298-1303

Li, W. K. W., Subba-Rao, D. V., Harrison, W. G., Smith, J. C. Cullen, J. C. (1983). Autotrophic picoplankton in the tropical ocean. Science 219: 292-295

Maeda, M., Lee, W. J., Taga, N. (1983). Distribution of lipopolysaccharide, an indicator of bacterial biomass, in subtropical areas of the sea. Mar. Biol. 76: 257-262

Menzel, D. W., Ryther, J. H. (1961). Annual variations in primary production of the Sargasso Sea off Bermuda. Deep Sea Res. 7: 282-288

Mopper, K., Sikorski., R. J., Kiever, D. J., McDaniel, J. A (1987). Photochemical incorporation and fragmentation of DOM in relation to oceanic carbon cycling. EOS Trans. Am. geophys. Un. 68: 1752

Mopper, K., Zika, R. (1987). Free amino acids in marine rains evidence of oxidation and potential role in nitrogen $\mathrm{cy}$ cling Nature Lond. 325: 246-249

Proctor, L. M., Fuhrman, J. A., Ledbetter, M. C. (1988) Marine bacteriophages and bacterial mortality. EOS Trans. Am. geophys. Un. 69: 1111

Ryther, J H., Dunstan, W M. (1971). Nitrogen, phosphorus, and eutrophication in the coastal marine environment. Science 171 1008-1013

Sherr, E. B., Sherr, B. F. (1987). High rates of consumption of bacteria by pelagic ciliates. Nature, Lond. 325: 710-711 
Sieburth, J. McN., Davis, P. G. (1982). The role of heterotrophic nanoplankton in the grazing and nurturing of planktonic bacteria in the Sargasso and Caribbean Seas. Annls Inst. oceanogr., Paris 58 (5): 285-296 (1982)

Smith, R. E. H., Geider, R. J., Platt, T (1984). Microplankton productivity in the oligotrophic ocean. Nature, Lond. 311: 252-254

Stockner, J. G., Antia, N. J. (1986). Algal picoplankton from marine and freshwater ecosystems: a multidisciplinary perspective. Can. J. Fish. aquat. Sci. 43: 2472-2503

Strathmann, R. R. (1967). Estimating the organic carbon content of phytoplankton from cell volume or plasma volume. Limnol. Oceanogr 12: 411-418

Strickland, J. D. H. (1960). Measuring the production of marine phytoplankton. Bull. Fish. Res. Bd Can. 122: 1-172

This article was presented by Dr N. S. Fisher, Stony Brook, New York, USA
Takahashi, M., Hori, T. (1984). Abundance of picophytoplankton in the subsurface chlorophyll maximum layer in subtropical and tropical waters. Mar Biol. 79: 177-186

Welschmeyer, N. A., Lorenzen, C. J. (1984). Carbon-14 labeling of phytoplankton carbon and chlorophyll a carbon: determination of specific growth rates. Limnol. Oceanogr. 29: $135-145$

Williams, P. J. LeB. (1981). Incorporation of microheterotrophic processes into the classical paradigm of the planktonic food web. Kieler Meeresforsch. Sonderh. 5: $1-28$

Williams, P. J. LeB. (1984). Bacterial production in the marine food chain: the emperor's new suit of clothes? In: Fasham, M. J. R. (ed.) Flows of energy and materials in marine ecosystems. Plenum, New York, p. 271-299

Manuscript first received: November 21, 1988

Revised version accepted: August 7, 1989 